University of Nebraska - Lincoln

DigitalCommons@University of Nebraska - Lincoln

Agronomy \& Horticulture -- Faculty Publications

Agronomy and Horticulture Department

2019

\title{
Do Cover Crops and Corn Residue Removal Affect Soil Thermal Properties?
}

\author{
Michael Sindelar \\ University of Nebraska-Lincoln, msindelar2@unl.edu \\ Humberto Blanco-Canqui \\ University of Nebraska-Lincoln, hblanco2@unl.edu \\ Virginia L. Jin \\ USDA, Agricultural Research Service \\ Richard B. Ferguson \\ University of Nebraska-Lincoln, rferguson1@unl.edu
}

Follow this and additional works at: https://digitalcommons.unl.edu/agronomyfacpub

Part of the Agricultural Science Commons, Agriculture Commons, Agronomy and Crop Sciences Commons, Botany Commons, Horticulture Commons, Other Plant Sciences Commons, and the Plant Biology Commons

Sindelar, Michael; Blanco-Canqui, Humberto; Jin, Virginia L.; and Ferguson, Richard B., "Do Cover Crops and Corn Residue Removal Affect Soil Thermal Properties?" (2019). Agronomy \& Horticulture -- Faculty Publications. 1285.

https://digitalcommons.unl.edu/agronomyfacpub/1285

This Article is brought to you for free and open access by the Agronomy and Horticulture Department at DigitalCommons@University of Nebraska - Lincoln. It has been accepted for inclusion in Agronomy \& Horticulture -Faculty Publications by an authorized administrator of DigitalCommons@University of Nebraska - Lincoln. 


\section{Do Cover Crops and Corn Residue Removal Affect Soil Thermal Properties?}

\section{Michael Sindelar}

Humberto Blanco-Canqui*

Dep. of Agronomy \& Horticulture

Univ. of Nebraska-Lincoln

Lincoln, NE 68583-0702

Virginia L. Jin

USDA-ARS

Lincoln, NE 68583-0937

\section{Richard Ferguson}

Dep. of Agronomy \& Horticulture

Univ. of Nebraska-Lincoln

Lincoln, NE 68583-0702

\section{Core Ideas}

- Corn residue removal reduces soil thermal conductivity and volumetric heat capacity.

- Cover crops do not mitigate corn residue removal effects on thermal properties.

- Soil water content and soil bulk density are strong predictors of soil thermal properties.
Soil thermal properties govern the transport and storage of heat in the soil. How management practices such as crop residue removal and cover crop (CC) use affect these soil properties is not well understood. For example, CCs could provide physical cover and improve soil properties after main crop residue removal and thus ameliorate the negative effects of residue removal on soil thermal properties. We measured changes in soil thermal properties including soil thermal conductivity, thermal diffusivity, volumetric heat capacity, and related properties under corn (Zea mays L.) residue removal with and without winter cereal rye (Secale cereale L.) under a 6-yr irrigated no-till continuous corn experiment on a silt loam in south central Nebraska. Cover crops did not affect thermal properties, but corn residue removal reduced field thermal conductivity by 12 to $41 \%$ and volumetric heat capacity by 6 to $49 \%$ during the growing season for the 0 - to $5-\mathrm{cm}$ depth. Residue removal also reduced laboratory thermal conductivity by $19 \%$ at $-0.03-\mathrm{MPa}$ and by $28 \%$ at $-1.5-\mathrm{MPa}$ matric potential. Residue removal also reduced volumetric heat capacity in the laboratory by $23 \%$ at both matric potentials in the $0-$ to $10-\mathrm{cm}$ depth. Neither residue removal nor CC affected thermal diffusivity. Thermal conductivity was more strongly correlated with soil water content than with bulk density and soil organic C. Overall, CC had no effect on thermal properties, but corn residue removal could reduce the soil's ability to conduct heat relative to no removal.

Abbreviations: CC, Cover crop.

$\mathrm{E}$ xcessive crop residue removal for livestock, cellulosic ethanol, fiber production, and other off-farm uses could negatively affect soil physical properties such as thermal properties (Blanco-Canqui and Lal, 2007; Wilhelm et al., 2007; Karlen et al., 2011). The pertinent soil thermal properties include thermal conductivity, volumetric heat capacity, and thermal diffusivity. Soil thermal conductivity refers to the rate at which a soil can transfer heat, while volumetric heat capacity is the amount of heat needed to raise the temperature of the unit mass of soil by one degree. Thermal diffusivity is the ratio of soil thermal conductivity to soil volumetric heat capacity and refers to how fast heat travels through the soil (Hillel, 2004). These properties influence many soil processes including soil temperature distribution, soil water storage, seed germination, microbial activities, surface energy balance, and resilience of soil to potential climatic fluctuations (Richard and Cellier, 1998; Hillel, 2004; Adhikari et al., 2014).

Many discussed the effects of crop residue removal on soil properties (Wilhelm et al., 2007; Blanco-Canqui and Lal, 2009). For example, the influence of crop residues on the surface soil temperature and soil water content is well documented (Horton et al., 1996; Sauer et al., 1996). However, few specifically quantified how crop residue removal affects soil thermal properties such as thermal conductivity, volumetric heat capacity, and thermal diffusivity in the field and laboratory. 
Knowledge of changes in these specific thermal properties can be important to discern how residue management affects the rate and speed of heat movement in the soil and overall soil energy balance. The few previous studies found some inconsistent effects of crop residue management on soil thermal conductivity. For example, a laboratory study using clay loam and silty loam soil monoliths found no difference in thermal conductivity among bare soil, soil with fresh corn residue, and soil with weathered corn residue (Sauer et al., 1996). Another study on a silt loam soil found no differences in soil thermal conductivity among control, rotary hoeing, winter wheat (Triticum aestivum $\mathrm{L}$.) straw mulching, and wheat straw mulching with rotary hoeing (Dahiya et al., 2007). However, other studies on tillage and crop residue management generally found higher soil thermal conductivity under no-till than under conventionally tilled systems (Potter et al., 1985; Azooz and Arshad, 1995; Abu-Hamdeh, 2000). These few previous studies mostly focused on soil thermal conductivity and not all thermal properties.

If crop residue removal adversely affects soil thermal conductivity, volumetric heat capacity, and thermal diffusivity, CCs could be a companion management practice to mitigate the potential negative effects of crop residue removal on such soil properties (Fronning et al., 2008; Blanco-Canqui, 2013; Osborne et al., 2014). However, changes in soil thermal properties have not been widely studied under CCs in spite of their relevance to many soil processes. Only one study evaluated soil thermal properties under CCs (Haruna et al., 2017), which found that cereal rye, hairy vetch (Vicia villosa ssp. villosa), and Austrian winter pea (Pisum sativum ssp. arvense) increased volumetric heat capacity by $15 \%$ but did not affect thermal conductivity compared with no CCs on a silt loam in Missouri after 4 yr of management.

Soil thermal properties can be correlated with other soil properties including volumetric water content, bulk density, organic $\mathrm{C}$ conentration, and others. Thermal conductivity is often positively correlated with volumetric water content and bulk density and negatively with air-filled porosity and soil organic $\mathrm{C}$ concentration (Ghuman and Lal, 1985; Potter et al., 1985; AbuHamdeh and Reeder, 2000; Ochsner et al., 2001; Abu-Hamdeh, 2003; Adhikari et al., 2014). Soil volumetric heat capacity can have a positive relationship with volumetric water content, bulk density, and soil organic C concentration (Ghuman and Lal, 1985; Potter et al., 1985; Abu-Hamdeh, 2003; Adhikari et al., 2014; Lu et al., 2014). However, correlations of other soil thermal properties with soil properties have not been studied under the potentially interacting effects of crop residue removal and CC addition.

Furthermore, soil thermal properties have been mostly measured in the laboratory and not under field conditions over time. Field measurements better reflect the in situ soil behavior relative to laboratory measurements. Measuring thermal properties during the growing season can characterize temporal changes associated with wetting and drying cycles, surface sealing, crusting, and residue decomposition. These and other processes have the potential to alter soil porosity, soil organic $\mathrm{C}$ concentration, and other properties, which can directly change the extent to which crop residue and CC management affects thermal properties. Growing CCs may alter soil thermal properties differently from $\mathrm{CC}$ residues after $\mathrm{CC}$ termination.

Specifically, information on how soil thermal conductivity, volumetric heat capacity, and thermal diffusivity change under CC, crop residue management, and their interactions in irrigated cropping systems is needed. Most studies on thermal properties have been conducted in rainfed systems (Potter et al., 1985; Adhikari et al., 2014; Haruna et al., 2017). Crop residue production and CC performance often differ between irrigated and rainfed systems (Ruis et al., 2017) and may affect soil thermal properties differently.

The objectives of this study were to assess: (i) the impact of corn residue removal and CCs on soil thermal conductivity, volumetric heat capacity, thermal diffusivity and their relationships with measured soil properties, and (ii) how thermal properties change throughout the growing season under field conditions on an irrigated silt loam in south central Nebraska. Our first hypothesis was that corn residue removal would reduce thermal conductivity, volumetric heat capacity, and thermal diffusivity. Our second hypothesis was that CCs would ameliorate residue removal effects on soil thermal properties in spring when main crops are absent.

\section{MATERIALS AND METHODS Study Site}

This study was conducted using an ongoing experiment established in 2010 at the University of Nebraska-Lincoln (UNL)'s South Central Agricultural Laboratory near Clay Center, NE $\left(40.582^{\circ} \mathrm{N}\right.$ lat; $98.144^{\circ} \mathrm{W}$ long; $552 \mathrm{~m}$ asl). The soil was a silt loam (fine, smectitic, mesic Udic Argiustolls) with slope of $<3 \%$ (Soil Survey Staff, Natural Resources Conservation Service, United States Department of Agriculture, 2017). The site was under irrigated no-till continuous corn. The experimental design was a completely randomized split-split-split block in quadruplicate with four study factors. The factors were: (i) two irrigation levels (100 and 60\%), (ii) three amelioration practices (none, manure, and cereal rye CC), (iii) two corn residue removal rates ( 0 and 56\%), and (iv) two inorganic $\mathrm{N}$ fertilizer rates (125 and $200 \mathrm{~kg} \mathrm{~N} \mathrm{ha}^{-1}$ ) for a total of 96 experimental units $(2 \times 3 \times 2 \times 2 \times 4=96$; BlancoCanqui et al., 2014). Agronomic operations for crop years 2015 to 2017 are found in Table 1. Temperature and rainfall data are in Table 2. Our study on soil hydraulic properties was conducted on two study factors within the larger experiment. The first factor was CC (control and CC) and corn residue removal (no removal and $56 \%$ removal) was the second factor. These factors resulted in a total of 16 experimental units $(2 \times 2 \times 4=16)$. These 16 units were under full irrigation and $200 \mathrm{~kg} \mathrm{~N} \mathrm{ha}^{-1}$ treatments. Additional details of the full experiment design can be found in Blanco-Canqui et al. (2014).

\section{Field Measurements of Thermal Properties}

The commercially available KD2 Pro in tandem with a SH-1 sensor (Decagon Devices) was used to determine thermal conductivity, volumetric heat capacity, and thermal dif- 
Table 1. Information on the experiment management.

\begin{tabular}{|c|c|c|}
\hline Year & Date & Field operation \\
\hline \multirow[t]{8}{*}{2015} & 27 Jan & P fertilizer surface broadcasted $\left(11-52-0 ; 112 \mathrm{~kg} \mathrm{ha}^{-1}\right)$ to the whole field \\
\hline & $17 \mathrm{Apr}$ & $\begin{array}{l}\text { Herbicide applied to whole field (Roundup Power Max }\left[\mathrm{C}_{3} \mathrm{H}_{8} \mathrm{NO}_{5} \mathrm{P}\right] 2.34 \mathrm{~L} \mathrm{ha}^{-1} \text { ); termination of winter } \\
\text { rye (Secale cereale L.) }\end{array}$ \\
\hline & 1 May & Corn planted (Dekalb 60-67 [Bayer]; 84,000 seeds ha ${ }^{-1}$ ); Starter fertilizer (10-34-0; $65.5 \mathrm{~kg} \mathrm{ha}^{-1}$ ) \\
\hline & 22 Jun & $\mathrm{N}$ fertilizer injected (UAN+ 32-0-0; 125 or $200 \mathrm{~kg} \mathrm{~N}$ ha $^{-1}$; banded at a $12-\mathrm{cm}$ depth) \\
\hline & 20, 27 Jul; 3, 17, 26, 31 Aug & Irrigation water applied ( 3.4 and $2 \mathrm{~cm}$ water for full and deficit irrigation, respectively) \\
\hline & 16 Oct & Corn (Zea mays L.) grain harvested \\
\hline & 27 Oct & Corn residue removed \\
\hline & $3 \mathrm{Nov}$ & Winter rye cover crop planted $\left(112 \mathrm{~kg} \mathrm{ha}^{-1}\right)$ with no-till drill \\
\hline \multirow[t]{12}{*}{2016} & 27 Jan & Broadcasted P fertilizer (11-52-0; $\left.112 \mathrm{~kg} \mathrm{ha}^{-1}\right)$ to whole field. \\
\hline & $22 \mathrm{Apr}$ & Herbicide applied to whole field (Roundup Power Max $2.34 \mathrm{~L} \mathrm{ha}^{-1}$ ); termination of winter rye \\
\hline & 13 May & Corn planted (Dekalb, 60-67; 84,000 seeds ha ${ }^{-1}$ ) with starter fertilizer $\left(10-34-0 ; 65.5 \mathrm{~kg} \mathrm{ha}^{-1}\right)$ \\
\hline & 18 May & Herbicide applied to whole field (5.84 $\mathrm{L} \mathrm{ha}^{-1}$ Lumax [Syngenta] $+2.34 \mathrm{~L} \mathrm{ha}^{-1}$ Roundup) \\
\hline & 16 Jun & Nitrogen fertilizer injected (UAN 32-0-0; 125 or $200 \mathrm{~kg} \mathrm{~N} \mathrm{ha}^{-1}$; banded at a 12-cm depth) \\
\hline & 17 Jun & Herbicide applied to whole field (Roundup at $2.92 \mathrm{~L} \mathrm{ha}^{-1}$ ) \\
\hline & 20 Jun; 1, 8, 19, 27 Jul; 2, 17 Aug & Irrigation water applied ( 3.4 and $2 \mathrm{~cm}$ water for full and deficit irrigation, respectively) \\
\hline & 14 Oct & Corn grain harvested \\
\hline & 27 Oct & Corn residue removed \\
\hline & 31 Oct & Winter rye cover crop planted $\left(112 \mathrm{~kg} \mathrm{ha}^{-1}\right)$ with no-till drill \\
\hline & $6 \mathrm{Nov}$ & Beef (Bos taurus) feedlot manure surface broadcasted to amelioration treatment plots ( 25 fresh $\mathrm{Mg} \mathrm{ha}^{-1}$ ) \\
\hline & Dec & Surface broadcasted phosphorus fertilizer $\left(11-52-0 ; 112 \mathrm{~kg} \mathrm{ha}^{-1}\right)$ to whole field \\
\hline \multirow[t]{7}{*}{2017} & $11 \mathrm{Apr}$ & Herbicide applied to whole field (Roundup Power Max 3.50 L ha-1); termination of winter rye \\
\hline & 6 May & Corn planted (Dekalb, 60-67; 84,000 seeds ha ${ }^{-1}$ ) with starter fertilizer $\left(10-34-0 ; 65.5 \mathrm{~kg} \mathrm{ha}^{-1}\right)$ \\
\hline & 9 May & Herbicide applied to whole field (7.01 $\mathrm{L} \mathrm{ha}^{-1} \mathrm{Lumax}+3.51 \mathrm{~L} \mathrm{ha}^{-1}$ Roundup PowerMax) \\
\hline & 13 Jun & $\mathrm{N}$ fertilizer injected (UAN 32-0-0; 125 or $200 \mathrm{~kg} \mathrm{~N}$ ha $^{-1}$; banded at a $12-\mathrm{cm}$ depth) \\
\hline & 27 Jun; 5, 11, 26 Jul; 15 Aug & Irrigation water applied ( 3.4 and $2 \mathrm{~cm}$ water for full and deficit irrigation, respectively) \\
\hline & 19 Oct & Corn grain harvested \\
\hline & $2 \mathrm{Nov}$ & Corn residue removed \\
\hline
\end{tabular}

† UAN, urea ammonium nitrate.

fusivity using the transient line heat source method (Bristow, 1998). Field measurements were collected every $30 \mathrm{~d}$ from May to September in 2016 and from April to June in 2017. The measurement date in 2017 was moved up due to warmer spring conditions and an earlier planting date than in the previous year (Tables 1 and 2). Thermal properties were measured at one location per plot on non-trafficked rows. A probe guide was carefully placed flush with the soil and then the SH-1 metal pins were then gently inserted vertically into the soil until the bottom of the sensor head was flush with the probe guide. The probe was then left in the soil for $5 \mathrm{~min}$ to allow the probe and surrounding soil to reach equilibrium temperatures. The thermal properties were then measured and recorded. All measurements were collected between 1000 and 1200 h. Measurements were conducted by block rather than by treatment.

Table 2. Monthly precipitation and temperature from 2015 to 2017 for the experimental site in south central Nebraska.

\begin{tabular}{|c|c|c|c|c|c|c|c|c|c|c|}
\hline \multirow{3}{*}{ Month } & \multicolumn{3}{|c|}{ Precipitation (mm) } & & \multicolumn{6}{|c|}{ Mean temperature $\left({ }^{\circ} \mathrm{C}\right)$} \\
\hline & \multirow[t]{2}{*}{2015} & \multirow[t]{2}{*}{2016} & \multirow[t]{2}{*}{2017} & & \multicolumn{2}{|c|}{2015} & \multicolumn{2}{|c|}{2016} & \multicolumn{2}{|c|}{2017} \\
\hline & & & & & Min & Max & Min & Max & Min & Max \\
\hline January & 5.3 & 0.0 & 0.0 & & -10.4 & 5.6 & -8.4 & 2.1 & -7.8 & 1.3 \\
\hline February & 0.8 & 0.0 & 0.0 & & 12.2 & 2.2 & -5.3 & 7.4 & -4.7 & 10.4 \\
\hline March & 4.8 & 0.3 & 0.0 & & -3.6 & 15.8 & -1.2 & 15.5 & -1.4 & 12.4 \\
\hline April & 61.7 & 138.4 & 81.3 & & 3.6 & 18.4 & 3.7 & 18.2 & 3.7 & 17.1 \\
\hline May & 144.5 & 172.5 & 153.9 & & 9.0 & 20.9 & 8.7 & 22.0 & 8.7 & 22.5 \\
\hline June & 225.8 & 5.08 & 22.6 & & 15.7 & 27.9 & 17.0 & 31.3 & 15.4 & 30.1 \\
\hline July & 54.9 & 63.5 & 50.8 & & 17.2 & 29.7 & 18.0 & 30.1 & 18.5 & 31.2 \\
\hline August & 32.5 & 63.0 & 89.6 & & 15.1 & 28.2 & 16.7 & 28.3 & 14.3 & 27.2 \\
\hline September & 38.4 & 66.8 & 23.9 & & 15.5 & 27.8 & 13.0 & 25.4 & 12.3 & 26.8 \\
\hline October & 37.1 & 5.6 & 0.0 & & 5.5 & 20.9 & 5.6 & 21.5 & 4.2 & 18.4 \\
\hline November & 6.1 & 0.0 & 0.0 & & -0.6 & 12.1 & -0.2 & 14.0 & -2.9 & 11.9 \\
\hline December & 0.0 & 0.0 & $x$ & & -5.7 & 5.1 & -10.3 & 2.8 & $x$ & $X$ \\
\hline Total & 611.9 & 515.1 & 422.1 & Mean & 4.0 & 17.9 & 4.8 & 18.2 & 5.5 & 19.0 \\
\hline
\end{tabular}


At the time of thermal property measurements, $5 \mathrm{~cm}$ by 5 $\mathrm{cm}$ undisturbed soil cores were collected to determine bulk density and volumetric water content in the laboratory. Soil cores were collected adjacent to the soil thermal property measurement point. The cores were taken to the laboratory, trimmed, weighed, and then a subsample was oven dried at $105^{\circ} \mathrm{C}$ for $24 \mathrm{~h}$ to determine gravimetric water content. Bulk density was determined by the core method (Grossman and Reinsch, 2002). The gravimetric water content was multiplied by the bulk density to calculate volumetric water content.

\section{Laboratory Measurements of Thermal Properties}

For the laboratory measurements of soil thermal properties, $5 \mathrm{~cm}$ by $5 \mathrm{~cm}$ soil cores were collected in spring of 2016 from 0 - to $5-\mathrm{cm}$ and 5- to $10-\mathrm{cm}$ soil depths from each plot. To avoid soil compaction during sampling, the cores were carefully inserted into the soil by hand until soil occupied the full volume of the cores. The intact cores were carefully extracted using hand trowels to minimize disturbance of both the intact cores and the experimental plot. The cores were then stored in a cold room at $2.2^{\circ} \mathrm{C}$ until further processing. Also, six hand-probe samples (3.1-cm diam.) were collected from each plot from 0 - to $10-\mathrm{cm}$ depth and split into 5-cm depth increments and composited by depth. The composite samples were gently broken up along natural breakage lines and allowed to air dry. These samples were used to measure soil organic $\mathrm{C}$ concentration and soil particlesize distribution, which were then used to study correlations with thermal properties and other related soil properties.

A portion of the initial air-dried sample was crushed and passed through a 2-mm sieve to determine soil organic $\mathrm{C}$ concentration by the dry combustion method (Nelson and Sommers, 1996). Soil particle-size distribution was determined by the hydrometer method (Gee and Or, 2002). Briefly, $50 \mathrm{~g}$ of air-dried soil passed through a $2-\mathrm{mm}$ sieve were mixed with $5 \%(\mathrm{w} / \mathrm{v})$ sodium hexametaphosphate and deionized water, and allowed to
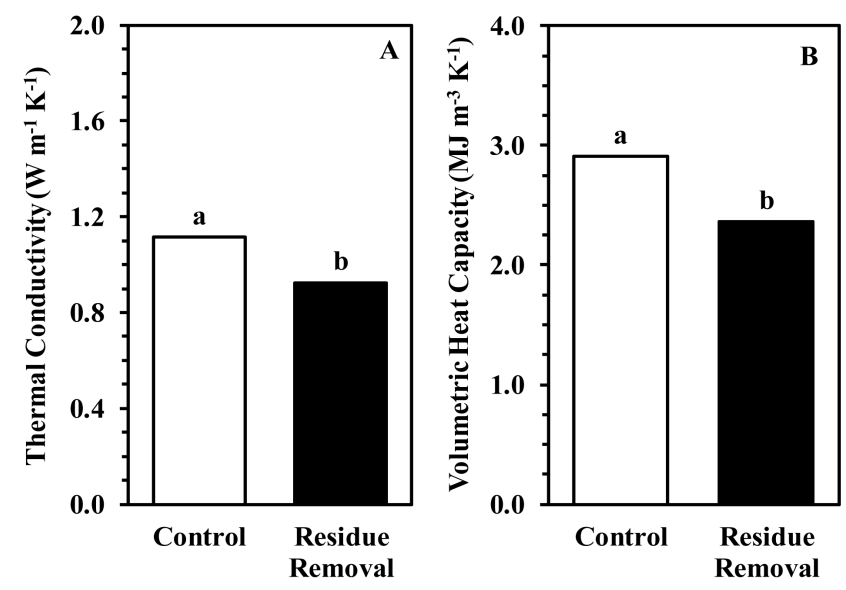

Fig. 1. Field measured soil thermal conductivity (A) and volumetric heat capacity (B) averaged across cover crop treatments and measurement dates as affected by corn residue removal at $56 \%$ for the 0 - to $5-\mathrm{cm}$ soil depth under irrigated no-till continuous corn on a silt loam in south central Nebraska. Different lowercase letters indicate significant differences between control and residue removal. stand for $24 \mathrm{~h}$. After dispersion using a multi-mix machine, the hydrometer readings were performed at $40 \mathrm{~s}$ and $3 \mathrm{~h}$ to determine the percentage of sand and silt (Gee and Or, 2002).

Soil cores taken for laboratory analysis of thermal properties were removed from cold storage and carefully trimmed so that the soil was flush with the top and bottom of the metal core. A serrated blade was used to avoid smearing the soil and blocking soil pores. The cores were then slowly saturated for about $48 \mathrm{~h}$. The saturated cores were weighed and transferred to a pressure extractor to equilibrate the water content of soil cores at $-0.033-\mathrm{MPa}$ matric potential and measure thermal properties at this potential. After equilibrium, which took about $15 \mathrm{~d}$, the cores were then removed, weighed, and the dual probe $\mathrm{SH}-1$ sensor was inserted into the core to measure soil thermal conductivity, soil volumetric heat capacity, and soil thermal diffusivity. Two measurements per core were performed by inserting the probes at least $1 \mathrm{~cm}$ from the edge of the core to avoid an edge effect during the measurement. The cores were then placed into a high pressure extractor to equilibrate the soil cores at $-1.5-\mathrm{MPa}$ matric potential, and after equilibrium, which took about $28 \mathrm{~d}$, thermal properties were measured at -1.5-MPa matric potential. Next, soil cores were weighed and oven-dried to determine gravimetric water content. The latter soil property was multiplied by the bulk density to calculate volumetric water content at each matric potential.

\section{Statistical Analysis}

Both laboratory and field measured data were tested for normality using PROC UNIVARIATE in SAS (SAS Institute Inc., 2017). Data were analyzed using a randomized complete block design with a split plot. The main plot was CC treatment and the split plot was the corn residue removal treatment. All laboratory data analysis was conducted by depth and soil matric potential. All data were analyzed using PROC MIXED to determine main effects and interactions. Significant differences among treatments were tested using LSMEANS in SAS at the 0.05 probability level unless otherwise noted. Relationships between soil thermal properties and other soil properties were studied using PROC CORR and PROC STEPWISE in SAS. Simple predictive equations for estimating thermal conductivity and volumetric heat capacity from other soil properties were developed using linear regression analysis.

\section{RESULTS}

Cover crop treatment had no effect on field or laboratory measured soil thermal properties. Laboratory measured data indicated that CCs had no effect at any soil depth. Similarly, CCs did not affect thermal properties at any measurement date in the field. However, corn residue removal had significant effects on both field and laboratory measured soil thermal properties except thermal diffusivity (Fig. 1A-B). Mean thermal diffusivity averaged across $\mathrm{CC}$ treatments was $0.40 \pm 0.09 \mathrm{~mm}^{2} \mathrm{~s}^{-1}$ for no residue removal and $0.39 \pm 0.04 \mathrm{~mm}^{2} \mathrm{~s}^{-1}$ for residue removal. 


\section{Soil Thermal Conductivity}

Under field conditions, residue removal reduced soil thermal conductivity by $17 \%$ in the 0 - to 5 -cm soil depth from spring 2016 to summer 2017 (Fig. 1A). Under laboratory conditions, residue removal reduced soil thermal conductivity at both matric potentials $(-0.033$ and $-1.5 \mathrm{MPa})$ for the 0 - to $5-\mathrm{cm}$ and 5 - to $10-\mathrm{cm}$ soil depth (Fig. 2A-B). At the 0- to 5-cm soil depth, residue removal reduced thermal conductivity by $26 \%$ at $-0.03 \mathrm{MPa}$ and by $29 \%$ at $-1.5 \mathrm{MPa}$ matric potentials compared with no residue removal. At the 5- to $10-\mathrm{cm}$ depth, residue removal also reduced thermal conductivity at both matric potentials, but to a lesser extent than at the 0 - to $5-\mathrm{cm}$ soil depth. At this depth, residue removal reduced thermal conductivity by $13 \%$ at $-0.03 \mathrm{MPa}$ and by $27 \%$ at $-1.5 \mathrm{MPa}$ matric potentials (Fig. 2B). Mean thermal conductivity averaged across $\mathrm{CC}$ treatments and matric potentials was $1.24 \pm 0.15 \mathrm{~W} \mathrm{~m}^{-1} \mathrm{~K}^{-1}$ for no residue removal and $1.14 \pm 0.13 \mathrm{~W} \mathrm{~m}^{-1} \mathrm{~K}^{-1}$ for residue removal.

\section{Soil Volumetric Heat Capacity}

Under field conditions, residue removal reduced soil volumetric heat capacity by $19 \%$ in the 0 - to 5 -cm soil depth from spring 2016 to summer 2017 (Fig. 1B). Under laboratory conditions, at the 0 - to $5-\mathrm{cm}$ soil depth, residue removal reduced volumetric heat capacity by $21 \%$ at $-0.03 \mathrm{MPa}$ and by $26 \%$ at $-1.5 \mathrm{MPa}$ matric potential compared with no removal (Fig. 3A). At the 5- to $10-\mathrm{cm}$ depth, residue removal reduced volumetric heat capacity by $6 \%$ at $-0.033 \mathrm{MPa}$ and by $19 \%$ at $-1.5 \mathrm{MPa}$ (Fig. 3B). Mean volumetric heat capacity averaged across CC treatments and matric potentials was $2.86 \pm 0.27 \mathrm{~mm}^{2} \mathrm{~s}^{-1}$ for no residue removal and $2.66 \pm 0.28 \mathrm{~mm}^{2} \mathrm{~s}^{-1}$

for residue removal.

\section{Correlation of Field Thermal Properties with Soil Water Content and Bulk Density}

Volumetric water content and bulk density measured on soil samples collected at the time of field thermal property measurements were used to study interrelationships among soil properties for the measurement depth (0to $5-\mathrm{cm}$ depth; Table 3). Cover crop had no effect on soil water content and bulk density, but residue removal affected water content throughout the sampling times (Table 3). Corn residue removal reduced volumetric water content by 13 to $40 \%$ compared with no removal (Table 3). Residue removal had no effect on soil bulk density.
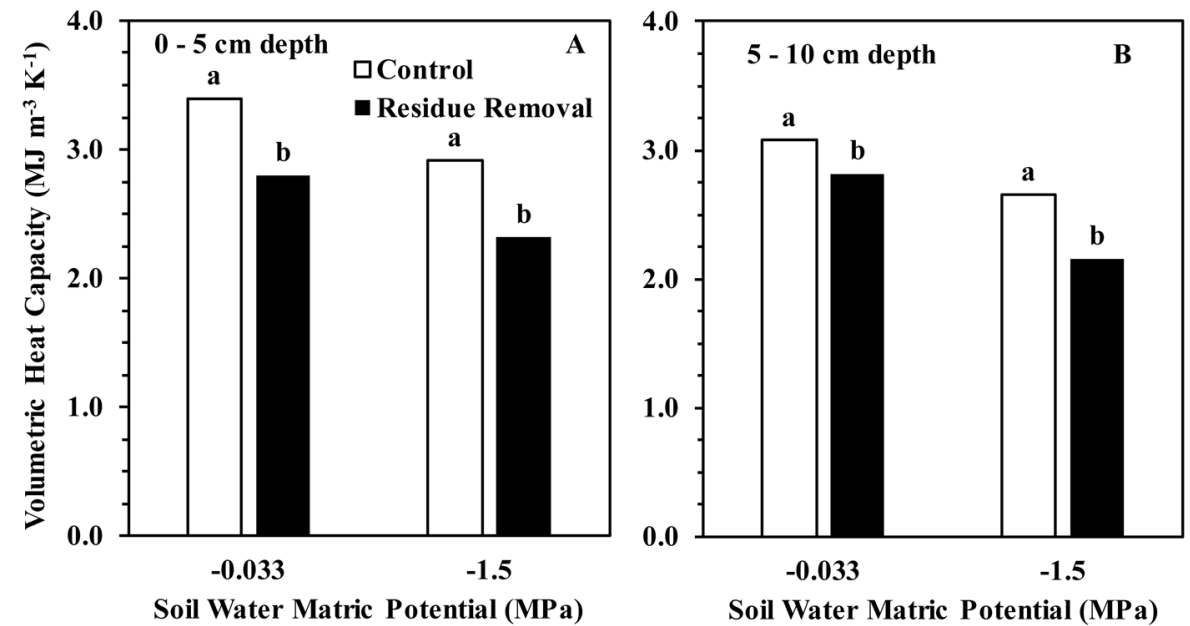

Fig. 3. Laboratory measured soil volumetric heat capacity at $-\mathbf{0 . 0 3 3}-$ and $-1.5-\mathrm{MPa}$ matric potentials for two corn residue removal treatments averaged across cover crop treatments for the 0 - to $5-\mathrm{cm}(A)$ and 5 - to $10-\mathrm{cm}$ (B) soil depths in an irrigated no-till continuous corn on a silt loam in south central Nebraska after 6 yr of management. Different lowercase letters indicate significant differences between control and residue removal. 
depth (Table 4). In the 5- to 10-cm depth, CC $\times$ residue removal interaction was significant for water content at -0.033 MPa potential, indicating that the magnitude by which residue removal decreased the water content depended on the presence of CCs (Table 4). Residue removal reduced water content by $15 \%$ at $-0.033 \mathrm{MPa}$ in plots without CC, while, averaged across CC treatments, it reduced water content by $11 \%$ at $-1.5 \mathrm{MPa}$. Residue removal did not affect bulk density and particle size at any depth (Table 5). Residue removal reduced soil organic C concentration, but the $\mathrm{CC} \times$ removal interaction was significant. Under plots without CC, residue removal reduced organic C concentration by $42 \%$ in the 0 - to $5-\mathrm{cm}$ and by $12 \%$ in the 5- to 10-cm depth. As expected, soil particle-size distribution did not significantly differ among treatments (Table 5).

Thermal conductivity and volumetric heat capacity were correlated with the above soil properties more for the $-0.033-\mathrm{MPa}$

Table 3. Mean volumetric water content and soil bulk density as affected by cover crop (CC) and corn residue removal treatments in an irrigated no-till continuous corn on a silt loam in south central Nebraska. The lowercase letters denote the statistical difference between residue management treatments by month under the same level of cover crop treatment.

\begin{tabular}{|c|c|c|c|c|}
\hline Date & $\begin{array}{l}\text { Cover } \\
\text { crop }\end{array}$ & $\begin{array}{l}\text { Residue } \\
\text { removal }\end{array}$ & $\begin{array}{c}\text { Volumetric } \\
\text { water content }\end{array}$ & $\begin{array}{l}\text { Bulk } \\
\text { density }\end{array}$ \\
\hline & & & $\mathrm{cm}^{3} \mathrm{~cm}^{-3}$ & $\mathrm{Mg} \mathrm{m}^{-3}$ \\
\hline \multirow{4}{*}{ April 2017} & No CC & No & $0.38 \mathrm{a}$ & 1.24 \\
\hline & & Yes & $0.25 b$ & 1.25 \\
\hline & $\mathrm{CC}$ & No & $0.38 \mathrm{a}$ & 1.28 \\
\hline & & Yes & $0.24 b$ & 1.25 \\
\hline \multirow[t]{4}{*}{ May 2017} & No CC & No & $0.32 \mathrm{a}$ & 1.25 \\
\hline & & Yes & $0.22 b$ & 1.27 \\
\hline & $\mathrm{CC}$ & No & $0.32 \mathrm{a}$ & 1.26 \\
\hline & & Yes & $0.24 b$ & 1.27 \\
\hline \multirow[t]{4}{*}{ June 2017} & No CC & No & $0.34 \mathrm{a}$ & 1.26 \\
\hline & & Yes & $0.19 b$ & 1.28 \\
\hline & $\mathrm{CC}$ & No & $0.32 \mathrm{a}$ & 1.29 \\
\hline & & Yes & $0.20 b$ & 1.26 \\
\hline \multirow[t]{4}{*}{ May 2016} & No CC & No & $0.39 \mathrm{a}$ & 1.28 \\
\hline & & Yes & $0.28 b$ & 1.25 \\
\hline & $\mathrm{CC}$ & No & $0.40 \mathrm{a}$ & 1.29 \\
\hline & & Yes & $0.30 b$ & 1.20 \\
\hline \multirow[t]{4}{*}{ June 2016} & No CC & No & $0.35 a$ & 1.28 \\
\hline & & Yes & $0.25 b$ & 1.25 \\
\hline & $\mathrm{CC}$ & No & $0.38 \mathrm{a}$ & 1.29 \\
\hline & & Yes & $0.28 b$ & 1.20 \\
\hline \multirow[t]{4}{*}{ July 2016} & No CC & No & $0.39 a$ & 1.28 \\
\hline & & Yes & $0.28 b$ & 1.25 \\
\hline & $\mathrm{CC}$ & No & $0.40 \mathrm{a}$ & 1.29 \\
\hline & & Yes & $0.30 b$ & 1.20 \\
\hline \multirow[t]{4}{*}{ August 2016} & No CC & No & $0.45 a$ & 1.28 \\
\hline & & Yes & $0.33 b$ & 1.25 \\
\hline & $\mathrm{CC}$ & No & $0.45 a$ & 1.27 \\
\hline & & Yes & $0.40 \mathrm{~b}$ & 1.20 \\
\hline \multirow[t]{4}{*}{ September 2016} & No CC & No & $0.40 \mathrm{a}$ & 1.28 \\
\hline & & Yes & $0.27 b$ & 1.25 \\
\hline & $\mathrm{CC}$ & No & $0.41 \mathrm{a}$ & 1.29 \\
\hline & & Yes & $0.31 b$ & 1.20 \\
\hline
\end{tabular}

than for the -1.5-MPa matric potential (Table 6). They were correlated more with bulk density and water content than with organic $\mathrm{C}$ at both depths (0- to 5-cm and 5- to 10-cm depths). In the 0 - to $5-\mathrm{cm}$ depth at -0.033 -MPa potential, both thermal conductivity and volumetric heat capacity increased with an increase in bulk density and water content. At the same matric potential, however, at the 5- to $10-\mathrm{cm}$ depth, thermal conductivity was positively correlated with soil organic $\mathrm{C}$ concentration and negatively correlated with clay content. At -1.5-MPa potential, thermal conductivity and volumetric heat capacity were positively correlated with bulk density at the 0 - to 5 -cm depth. At the 5- to 10-cm depth, thermal conductivity was positively correlated with soil organic $\mathrm{C}$ concentration, bulk density, and water content. At the same depth, volumetric heat capacity was positively correlated with soil organic $\mathrm{C}$ concentration and water content (Table 6).

Volumetric water content, bulk density, and organic $\mathrm{C}$ concentrations were important predictors of thermal conductivity and volumetric heat capacity (Table 7). The predictive ability of the three soil properties were in this order: volumetric water content $>$ bulk density $>$ organic $\mathrm{C}$ concentration. Volumetric water content and bulk density were the best predictors of thermal conductivity and volumetric heat capacity for $-0.03 \mathrm{MPa}$ matric potential at the 0 - to $5-\mathrm{cm}$ depth. Soil organic $\mathrm{C}$ concentration was a significant predictor of soil thermal conductivity at both matric potentials, but only at the 5 - to $10-\mathrm{cm}$ depth (Table 7). Soil organic $\mathrm{C}$ concentration was only a significant predictor of soil volumetric heat capacity for the 5 - to $10-\mathrm{cm}$ depth at $-1.5 \mathrm{MPa}$.

\section{DISCUSSION}

This study indicates that corn residue removal at about 56\% for $6 \mathrm{yr}$ had significant effects on soil thermal properties except thermal diffusivity in the 0 - to $10-\mathrm{cm}$ soil depth. These results partly support our first hypothesis, which stated that corn residue removal could decrease soil thermal conductivity, volumetric heat capacity, and thermal diffusivity. The residue removal effect on thermal conductivity and volumetric heat capacity were of a similar magnitude and direction, which resulted in no changes in thermal diffusivity. The latter is calculated as the ratio of thermal conductivity over volumetric heat capacity. An increase in volumetric heat capacity directly reduces thermal diffusivity (Horton et al., 1996). Unlike in previous studies where residue removal had no effect on thermal conductivity (Sauer et al., 1996; Dahiya et al., 2007), in this study, thermal conductivity was reduced by residue removal. The significant residue removal effect on soil thermal conductivity was most likely because of the extended period of study (six consecutive years of corn residue removal at 56\%), whereas the previous studies were short term $(<1 \mathrm{yr})$.

Cover crop had no effect on soil thermal properties, which did not support our second hypothesis. We hypothesized that CC use for 6 yr would have altered soil thermal properties by providing additional surface cover, and affecting soil porosity, soil organic $\mathrm{C}$ concentration, and other properties. We also hypothesized that $\mathrm{CC}$ use would mitigate residue removal effects on thermal properties. The lack of CC effect on thermal properties in this study 

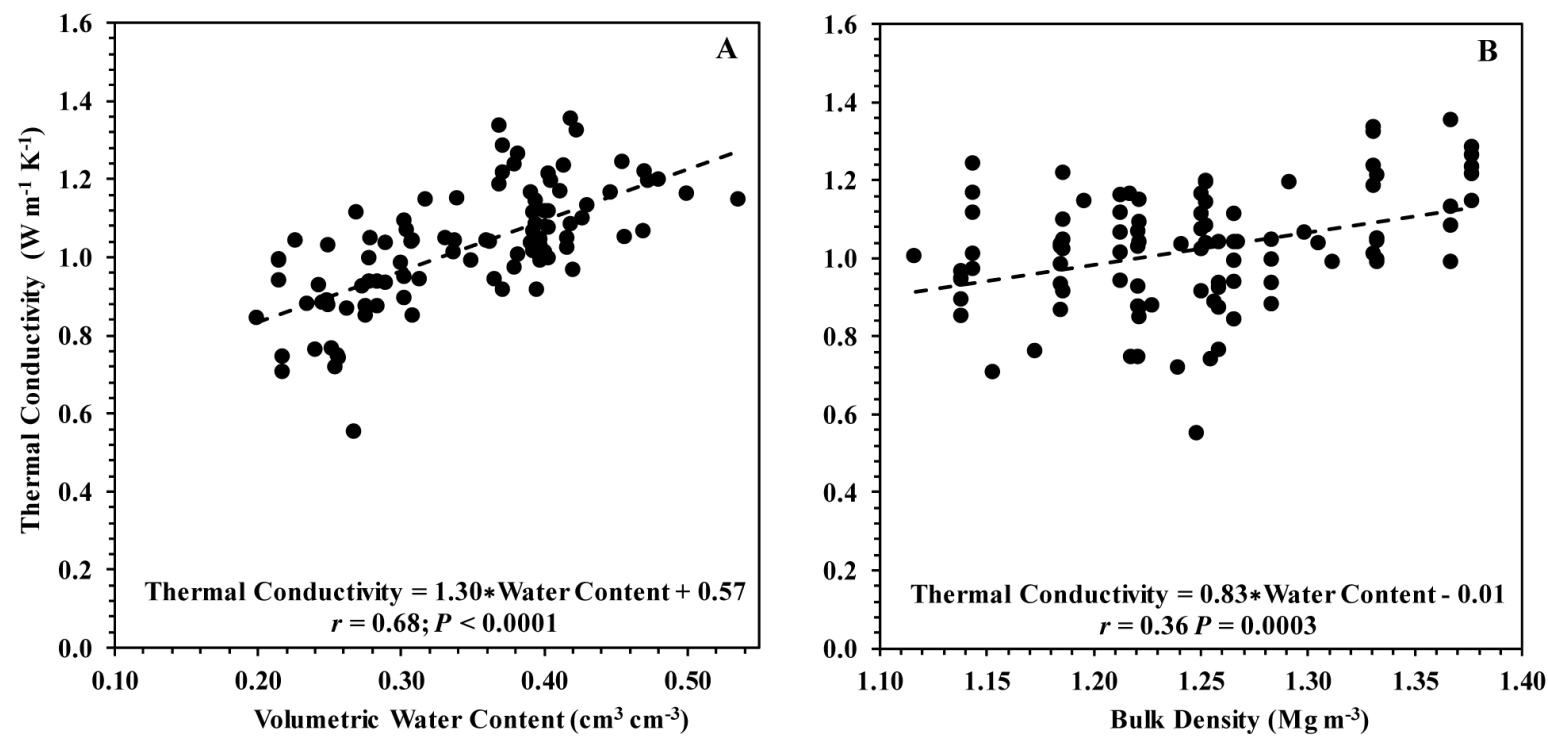

Fig. 4. Relationship of field measured soil thermal conductivity with volumetric water content (A) and bulk density (B) across corn residue removal and winter rye cover crop treatments under irrigated no-till continuous corn on a silt loam in south central Nebraska.

can be attributed to low CC biomass production. The aboveground CC biomass yield averaged across 6 yr was $0.8 \mathrm{Mg} \mathrm{ha}^{-1}$. This amount of yield is lower compared with that (1.66 to 3.24 $\mathrm{Mg} \mathrm{ha}^{-1} \mathrm{yr}^{-1}$ ) found in some recent studies under different CC management scenarios (Kaspar and Bakker, 2015; Blanco-Canqui et al., 2017). The lower CC biomass yield is probably because of the short CC growing period (early November to early April) in our study. Another study in Nebraska found that late-terminated CC (early May) can produce significantly more biomass than early-terminated CC (mid-April; Ruis et al., 2017).

Changes in soil thermal properties could depend on belowground CC biomass input as studies have shown that more soil organic $\mathrm{C}$ is gained from the roots of cereal rye than from the shoots (Puget and Drinkwater, 2001; Kong and Six, 2010, 2012). In our study, based on the low aboveg-

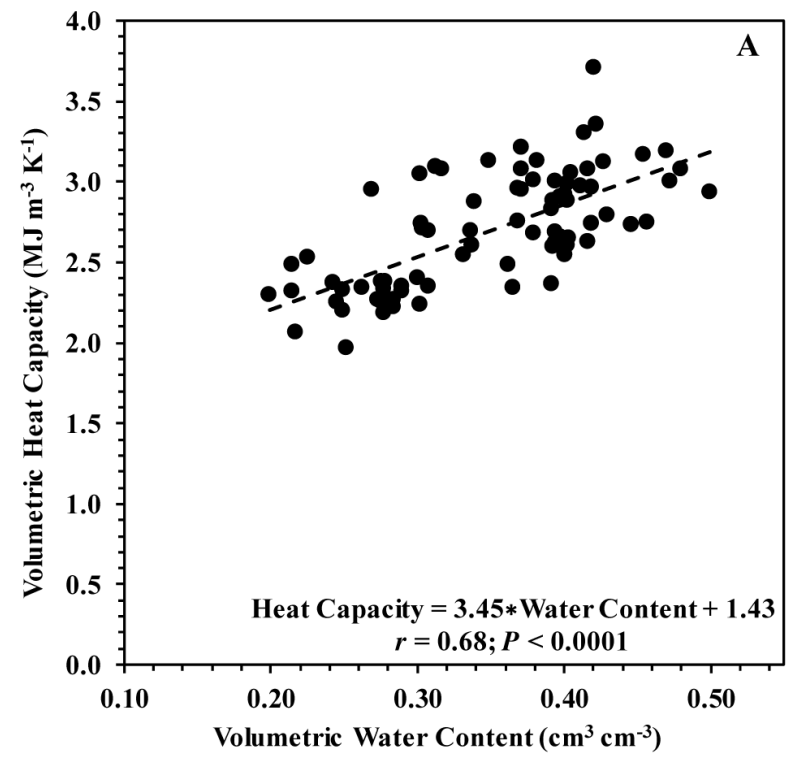

round biomass yield, root biomass yield was also probably low although we did not quantify the amount of root biomass. For example, cereal rye has been reported to have a 2.4 to 5 shoot/root ratio (Sheng and Hunt, 1991; Amanullah and Ullah, 2015), which suggests that the rye biomass yield in our study $\left(0.8 \mathrm{Mg} \mathrm{ha}^{-1} \mathrm{yr}^{-1}\right)$ would equal 0.16 to 0.40 to $\mathrm{Mg} \mathrm{ha}^{-1} \mathrm{yr}^{-1}$ of root biomass. Thus, it is estimated that winter rye added 0.96 to $1.20 \mathrm{Mg} \mathrm{ha}^{-1} \mathrm{yr}^{-1}$ of total biomass (aboveground and belowground biomass). This amount of CC biomass input was well below the amount of corn residue removed in this study, which, on average, amounted to $5.9 \mathrm{Mg} \mathrm{ha}^{-1}$ $\mathrm{yr}^{-1}$. Residue amount as well as plant residue type and residue orientation (standing vs. flat) can be important factors that affect soil heat fluxes (Flerchinger et al., 2003).

There is only one study from Missouri that has measured CC effects on soil thermal conductivity, volumetric heat ca-

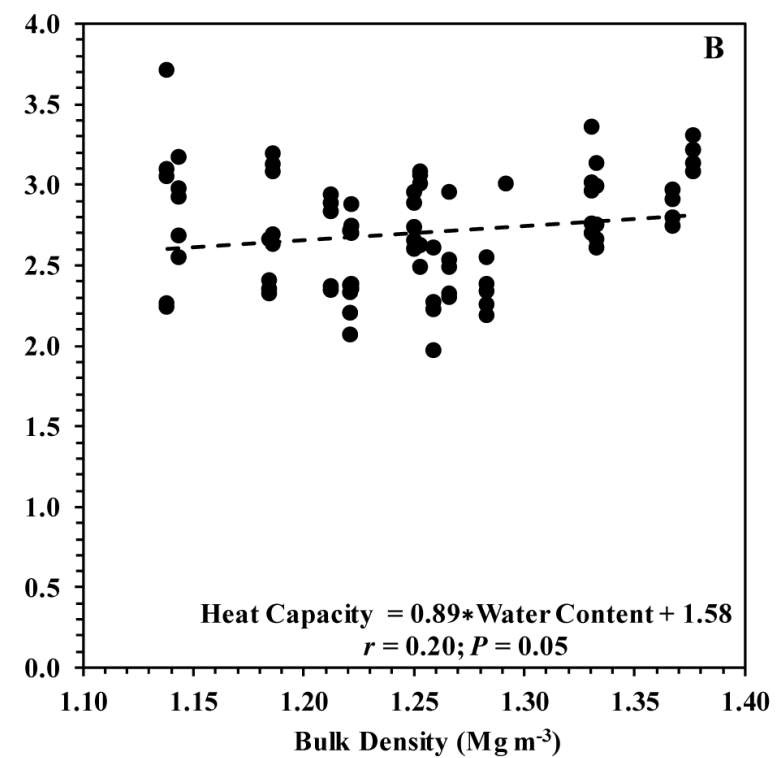

Fig. 5. Relationship of soil volumetric heat capacity with volumetric water content (A) and bulk density (B) across corn residue removal and winter rye cover crop treatments under irrigated no-till continuous corn on a silt loam in south central Nebraska after 6 yr of management. 
pacity, and thermal diffusivity (Haruna et al., 2017), which can be used to compare with our study results. While we did not find CC effects on thermal properties, Haruna et al. (2017) reported

Table 4. Mean volumetric water content $\left(\theta_{\mathrm{v}}\right)$ at matric potentials of -0.033 and $-1.5 \mathrm{MPa}$ as affected by covercrop and corn residue removal treatments in an irrigated no-till continuous corn on a silt loam in south central Nebraska. Cover crop and residue removal interaction was significant for the 5- to $10-\mathrm{cm}$ depth. The lowercase letters denote the statistical difference between residue management treatments.

\begin{tabular}{lccc} 
Treatment & Depth & \multicolumn{2}{c}{$\boldsymbol{\theta}_{\mathbf{v}}$} \\
\hline & \multicolumn{3}{c}{ at $-0.033 \mathrm{MPa}$} \\
$\mathrm{cm}^{3} \mathrm{~cm}^{-3}$ & $\mathrm{at}-1.5 \mathrm{MPa}$ \\
$\mathrm{cm}^{3} \mathrm{~m}^{-3}$ \\
No residue removal & $0-5$ & $0.40 \mathrm{a}$ & 0.18 \\
56\% residue removal & $0-5$ & $0.31 \mathrm{~b}$ & 0.17 \\
$\begin{array}{l}\text { No cover crop } \\
\text { No residue removal }\end{array}$ & $5-10$ & $0.38 \mathrm{a}$ & $0.24 \mathrm{a}$ \\
$\begin{array}{l}\text { 56\% residue removal } \\
\text { Cover crop }\end{array}$ & $5-10$ & $0.33 \mathrm{~b}$ & $0.22 \mathrm{~b}$ \\
$\quad$ & & \\
No residue removal & $5-10$ & 0.40 & $0.25 \mathrm{a}$ \\
$56 \%$ residue removal & $5-10$ & 0.38 & $0.22 \mathrm{~b}$ \\
\hline
\end{tabular}

Table 5. Mean soil organic C concentration, soil bulk density, particle density, and particle-size analysis as affected by cover crop (CC) and corn residue removal treatments in an irrigated no-till continuous corn on a silt loam in south central Nebraska. Cover crop and residue removal interaction was significant for both soil depths. The lowercase letters denote the statistical difference between residue management treatments.

\begin{tabular}{|c|c|c|c|c|c|c|}
\hline $\begin{array}{l}\text { Cover } \\
\text { crop }\end{array}$ & $\begin{array}{l}\text { Residue } \\
\text { removal }\end{array}$ & Depth & $\begin{array}{c}\text { Soil } \\
\text { organic C }\end{array}$ & $\begin{array}{c}\text { Bulk } \\
\text { density }\end{array}$ & Clay & Silt \\
\hline & & $\mathrm{cm}$ & $\mathrm{g} \mathrm{kg}^{-1}$ & $M g \mathrm{~m}^{-3}$ & $\mathrm{~g} \mathrm{~kg}^{-1}$ & $\mathrm{~g} \mathrm{~kg}^{-1}$ \\
\hline \multirow[t]{2}{*}{ No CC } & No & $0-5$ & $25.4 \mathrm{a}$ & 1.34 & 288 & 570 \\
\hline & Yes & $0-5$ & $17.9 \mathrm{~b}$ & 1.24 & 300 & 578 \\
\hline \multirow[t]{2}{*}{ CC } & No & $0-5$ & 23.7 & 1.23 & 218 & 625 \\
\hline & Yes & $0-5$ & 22.4 & 1.26 & 283 & 590 \\
\hline \multirow[t]{2}{*}{ No CC } & No & $5-10$ & $16.7 \mathrm{a}$ & 1.43 & 284 & 572 \\
\hline & Yes & $5-10$ & $14.9 \mathrm{~b}$ & 1.41 & 298 & 576 \\
\hline \multirow[t]{2}{*}{$\mathrm{CC}$} & No & $5-10$ & 16.4 & 1.44 & 235 & 615 \\
\hline & Yes & $5-10$ & 15.9 & 1.40 & 299 & 571 \\
\hline
\end{tabular}

Table 6. Correlations between laboratory thermal properties and other laboratory soil properties across both cover crop and residue removal treatments by depth in an irrigated no-till continuous corn on a silt loam soil in south central Nebraska.

\begin{tabular}{|c|c|c|c|c|}
\hline Property & Depth & $\begin{array}{c}\text { Water } \\
\text { content }\end{array}$ & $\begin{array}{c}\text { Bulk } \\
\text { density }\end{array}$ & $\begin{array}{c}\text { Soil } \\
\text { organic C }\end{array}$ \\
\hline & $\mathrm{cm}$ & $\mathrm{cm}^{3} \mathrm{~cm}^{-3}$ & $\mathrm{Mg} \mathrm{m}^{-3}$ & $\mathrm{~g} \mathrm{~kg}^{-1}$ \\
\hline & \multicolumn{4}{|c|}{-0.033 MPa Soil Water Matric Potential } \\
\hline Thermal conductivity, $\mathrm{W} \mathrm{m}^{-1} \mathrm{~K}^{-1}$ & $0-5$ & $0.72 * *$ & $0.50^{*}$ & 0.28 \\
\hline 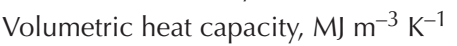 & $0-5$ & $0.65^{* *}$ & $0.62^{* *}$ & $0.43+$ \\
\hline Thermal conductivity, $\mathrm{W} \mathrm{m}^{-1} \mathrm{~K}^{-1}$ & $5-10$ & $0.59^{*}$ & $0.59 *$ & $0.74^{* *}$ \\
\hline \multirow[t]{2}{*}{ Volumetric heat capacity, MJ m-3 $\mathrm{K}^{-1}$} & $5-10$ & $0.62^{* *}$ & $0.45+$ & 0.45 \\
\hline & \multicolumn{4}{|c|}{-1.5 MPa Soil Water Matric Potential } \\
\hline Thermal conductivity, $\mathrm{W} \mathrm{m}^{-1} \mathrm{~K}^{-1}$ & $0-5$ & 0.16 & $0.41+$ & 0.28 \\
\hline 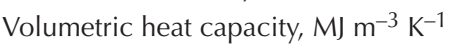 & $0-5$ & -0.10 & $0.64^{* *}$ & 0.18 \\
\hline Thermal conductivity, $\mathrm{W} \mathrm{m}^{-1} \mathrm{~K}^{-1}$ & $5-10$ & $0.71^{* *}$ & $0.51^{*}$ & $0.55^{*}$ \\
\hline Volumetric heat capacity, $\mathrm{MJ} \mathrm{m}^{-3} \mathrm{~K}^{-1}$ & $5-10$ & $0.71^{* *}$ & 0.34 & $0.48+$ \\
\hline
\end{tabular}

$*, * *$, and ${ }^{* * *}$, significant at $0.05,0.01$, and 0.001 probability levels.

+ Significant at 0.10 probability level. that CCs increased volumetric heat capacity and decreased thermal diffusivity but had no effect on soil thermal conductivity. The contrasting results may be due to the agronomic differences. For example, our experiment used a single CC species with early spring termination under irrigated conditions, while Haruna et al. (2017) used three-species CC mix with late spring termination in a rainfed system. In particular, the later spring termination date likely facilitated greater $\mathrm{CC}$ biomass accumulation and concomitant changes in soil thermal properties in the study by Haruna et al. (2017).

Results from this study suggest that changes in thermal conductivity and volumetric heat capacity because of corn residue removal are associated with changes in volumetric water content, bulk density, and soil organic C concentration. Volumetric water content had the strongest correlation with thermal conductivity at both depths (0- to 5-cm and 5- to 10-cm depth) at the -0.033-MPa matric potential compared with other measured soil properties (Table 6). Additionally, volumetric water content explained $52 \%$ of variability in thermal conductivity for the 0 - to 5-cm depth at the -0.033-MPa potential (Table 7). The positive correlation of thermal conductivity with volumetric water content and bulk density is similar to the relationships reported by previous studies (Abu-Hamdeh and Reeder, 2000; Adhikari et al., 2014; Haruna et al., 2017). Water films between soil particles and within aggregates act as heat conducting bridges (Ghuman and Lal 1985; Abu-Hamdeh and Reeder, 2000). Thus, a reduction in volumetric water content may have resulted in less bridging water films decreasing thermal conductivity. Additionally, it is well known that water-filled pore space has higher thermal conductivity and specific heat values compared with air-filled pore space because water $\left(0.57 \mathrm{~W} \mathrm{~m}^{-1} \mathrm{~K}^{-1}\right)$ has higher thermal conductivity than air $\left(0.025 \mathrm{~W} \mathrm{~m}^{-1} \mathrm{~K}^{-1}\right.$; Hillel 2004). The drier the soil, the lower the thermal conductivity and volumetric heat capacity.

Although residue removal and CC had no effects on soil bulk density, bulk density generally correlated with more changes in thermal properties compared with soil organic $\mathrm{C}$ concentration. An increase in bulk density most likely decreased the space required by heat to travel between soil particles increasing thermal conductivity (Abu-Hamdeh, 2003). In this study, soil organic $\mathrm{C}$ had a positive relationship with thermal conductivity although most previous studies found a negative relationship (Abu-Hamdeh and Reeder, 2000; Adhikari et al., 2014; Haruna et al., 2017). While an increase in soil organic C concentration often reduces thermal conductivity (Hillel, 2004), we suggest that, in our study, a decrease in organic $\mathrm{C}$ concentration with residue removal may have reduced soil thermal conductivity by reducing the ability of the soil to retain water.

The decrease in soil thermal conductivity and soil volumetric heat capacity with residue removal in this study can have implications for soil-surface energy balance (Horton et al., 1996). The lower thermal conductivity and volumetric heat capacity under residue removal suggests that the soil surface in fields with residue removed can warm and cool 
Table 7. Predictive equations of soil thermal conductivity and volumetric heat capacity using measured soil properties as input parameters across both cover crop and residue removal treatments by soil depth in an irrigated no-till continuous corn on a silt loam soil in south central Nebraska.

\begin{tabular}{|c|c|c|c|c|c|c|c|}
\hline \multirow{2}{*}{$\begin{array}{l}\text { Depth, } \\
\text { cm }\end{array}$} & \multirow[b]{2}{*}{ Variable } & \multicolumn{3}{|c|}{-0.033 MPa Matric potential } & \multicolumn{3}{|c|}{-1.5 MPa Matric potential } \\
\hline & & Partial $r^{2}$ & Model $r^{2}$ & $P>F$ & Partial $r^{2}$ & Model $r^{2}$ & $P>F$ \\
\hline & & \multicolumn{6}{|c|}{ Soil Thermal Conductivity } \\
\hline \multirow[t]{2}{*}{$0-5$} & Water content, $\mathrm{cm}^{3} \mathrm{~cm}^{-3}$ & 0.52 & 0.52 & 0.04 & 0.20 & 0.40 & 0.05 \\
\hline & Bulk density, $\mathrm{Mg} \mathrm{m}^{-3}$ & 0.17 & 0.69 & 0.02 & & & \\
\hline \multirow[t]{4}{*}{$5-10$} & Soil organic $\mathrm{C}, \mathrm{g} \mathrm{kg}^{-1}$ & 0.55 & 0.55 & $<0.01$ & 0.23 & 0.74 & $<0.01$ \\
\hline & Bulk density, $\mathrm{Mg} \mathrm{m}^{-3}$ & 0.09 & 0.64 & 0.03 & & & \\
\hline & Water content, $\mathrm{cm}^{3} \mathrm{~cm}^{-3}$ & 0.07 & 0.84 & 0.09 & 0.53 & 0.53 & $<0.01$ \\
\hline & & \multicolumn{6}{|c|}{ Soil Volumetric Heat Capacity } \\
\hline \multirow[t]{2}{*}{$0-5$} & Water content, $\mathrm{cm}^{3} \mathrm{~cm}^{-3}$ & 0.42 & 0.42 & $<0.01$ & & & \\
\hline & Bulk density, $\mathrm{Mg} \mathrm{m}^{-3}$ & 0.30 & 0.72 & 0.03 & 0.41 & 0.41 & $<0.01$ \\
\hline \multirow[t]{3}{*}{$5-10$} & Bulk density, $\mathrm{Mg} \mathrm{m}^{-3}$ & 0.50 & 0.50 & 0.04 & & & \\
\hline & Water content, $\mathrm{cm}^{3} \mathrm{~cm}^{-3}$ & & & & 0.50 & 0.50 & $<0.01$ \\
\hline & Soil organic C, $\mathrm{g} \mathrm{kg}^{-1}$ & & & & 0.17 & 0.67 & 0.02 \\
\hline
\end{tabular}

more rapidly than fields with residues because soils without residues will have reduced ability to transfer and distribute heat to lower soil depths. In addition, the lower volumetric heat capacity of soils with residue removed imply that these soils could require less heat to increase soil temperature when compared with fields with residues (Kenney et al., 2015). The extra amount of heat on the surface can lead to increased surface temperature and conversion to latent heat as evapotranspiration. Overall, soils with residue removed can reduce both heat distribution in the soil profile and water storage but may increase freeze-thaw and dry-wet cycles, increase residue decomposition, and possibly facilitate early planting of crops in spring.

\section{CONCLUSIONS}

Our study indicates that corn residue removal at $56 \%$ for 6 yr reduced soil thermal conductivity and volumetric heat capacity in the upper 10-cm depth of soil but had no effect on soil thermal diffusivity in an irrigated no-till continuous corn on a silt loam in south central Nebraska. The presence of winter rye $\mathrm{CC}$, however, did not ameliorate the negative effects of residue removal on soil thermal conductivity and volumetric heat capacity in this system. We attribute the lack of CC effect to the limited CC biomass production in this study. Planting CC after corn grain harvest in late October or early November and terminating CC in early spring about a month before corn planting resulted in low CC biomass accumulation $\left(<0.8 \mathrm{Mg} \mathrm{ha}^{-1} \mathrm{yr}^{-1}\right)$. Similarly, other soil properties related to thermal properties were significantly affected by corn residue removal but not by CC. In this study, soil volumetric water content was the most common predictor of soil thermal conductivity and volumetric heat capacity followed by bulk density, and soil organic $\mathrm{C}$ concentration. Results indicate that residue removal at approximately $56 \%$ could create a soil microclimate by reducing heat flow through the soil profile and increasing surface soil temperature. In summary, our study indicates that corn residue removal can alter soil thermal conductivity and volumetric heat capacity, but winter rye CC may not be able to mitigate the negative effects of residue removal on such properties under the conditions of this study.

\section{REFERENCES}

Abu-Hamdeh, N.H. 2000. Effect of tillage treatments on soil thermal conductivity for some Jordanian clay loam and loam soils. Soil Tillage Res. 56:145-151. doi:10.1016/S0167-1987(00)00129-X

Abu-Hamdeh, N.H. 2003. Thermal properties of soils as affected by density and water content. Biosyst. Eng. 86:97-102. doi:10.1016/S1537-5110(03)00112-0

Abu-Hamdeh, N.H., and R.C. Reeder. 2000. Soil thermal conductivity effects of density, moisture, salt concentration, and organic matter. Soil Sci. Soc. Am. J. 64:1285-1290. doi:10.2136/sssaj2000.6441285x

Adhikari, P., R.P. Udawatta, and S.H. Anderson. 2014. Soil thermal properties under prairies, conservation buffers, and corn-soybean land use systems. Soil Sci. Soc. Am. J. 78:1977-1986. doi:10.2136/sssaj2014.02.0074

Amanullah, B.A.S., and H. Ullah. 2015. Cool season C3-grasses (wheat, rye, barley, and oats) differ in shoot: Root ratio when applied with different NPK sources. J. Plant Nutr. 38:189-201. doi:10.1080/01904167.2014.881877

Azooz, R.H., and M.A. Arshad. 1995. Tillage effects on thermal conductivity of two soils in northern British Columbia. Soil Sci. Soc. Am. J. 59:14131423. doi:10.2136/sssaj1995.03615995005900050030x

Blanco-Canqui, H., and R. Lal. 2007. Soil and crop response to harvesting corn residues for biofuel production. Geoderma 141:355-362. doi:10.1016/j. geoderma.2007.06.012

Blanco-Canqui, H., and R. Lal. 2009. Crop residue removal impacts on soil productivity and environmental quality. Crit. Rev. Plant Sci. 28:139-163. doi: $10.1080 / 07352680902776507$

Blanco-Canqui, H. 2013. Crop residue removal for bioenergy reduces soil carbon pools: How can we offset carbon losses? BioEnergy Res. 6:358371. doi:10.1007/s12155-012-9221-3

Blanco-Canqui, H., R.B. Ferguson, V.L. Jin, M.R. Schmer, B.J. Wienhold, and J. Tatarko. 2014. Can cover crop and manure maintain soil properties after residue removal from irrigated no-till corn? Soil Sci. Soc. Am. J. 78:13681377. doi: 10.2136/sssaj2013.12.0550

Blanco-Canqui, H., M. Sindelar, C.S. Wortmann, and G. Kreikemeier. 2017. Aerial interseeded cover crop and corn residue harvest: Soil and crop impacts. Agron. J. 109:1344-1351. doi:10.2134/agronj2017.02.0098

Bristow, K.L. 1998. Measurement of thermal properties and water content of unsaturated sandy soil using dual-probe heat-pulse probes. Agric. For. Meteorol. 89:75-84. doi:10.1016/S0168-1923(97)00065-8

Dahiya, R., J. Ingwersen, and T. Streck. 2007. The effect of mulching and tillage on the water and temperature regimes of a loess soil: Experimental findings and modeling. Soil Tillage Res. 96:52-63. doi:10.1016/j.still.2007.02.004

Flerchinger, G.N., T.J. Sauer, and R.A. Aiken. 2003. Effects of crop residue cover and architecture on heat and water transfer at the soil surface. Geoderma 116:217-233. doi: 10.1016/S0016-7061(03)00102-2

Fronning, B.E., K.D. Thelen, and D.H. Min. 2008. Use of manure, compost, 
and cover crops to supplant crop residue carbon in corn stover removed cropping systems. Agron. J. 100:1703-1710.

Gee, G.W., and D. Or. 2002. Particle-size analysis. In: J.H. Dane and G.C. Topp, editors, Methods of soil analysis. Part 4. SSSA Book Ser. 5. SSSA, Madison, WI. p. 255-293.

Ghuman, B.S., and R. Lal. 1985. Thermal conductivity, thermal diffusivity, and thermal capacity of some Nigerian soils. Soil Sci. 139:74-80. doi:10.1097/00010694-198501000-00011

Grossman, R.B., and T.G. Reinsch. 2002. Bulk density and linear extensibility. In: J.H. Dane and G.C. Topp, editors, Methods of soil analysis. Part 4. SSSA Book Ser. 5. SSSA, Madison, WI. p. 201-225.

Haruna, S.I., S.H. Anderson, N.V. Nkongolo, T. Reinbott, and S. Zaibon. 2017. Soil thermal properties influenced by perennial biofuel and cover crop management. Soil Sci. Soc. Am. J. 81:1147-1156. doi:10.2136/sssaj2016.10.0345

Hillel, D. 2004. Introduction to environmental soil physics. Academic press, Cambridge, MA.

Horton, R., K.L. Bristow, G.J. Kluitenberg, and T.J. Sauer. 1996. Crop residue effects on surface radiation and energy balance. Theor. Appl. Climatol. 54:27-37. doi:10.1007/BF00863556

Karlen, D.L., G.E. Varvel, J.M.F. Johnson, J.M. Baker, S.L. Osborne, J.M. Novak, P.R. Adler, G.W. Roth, and S.J. Birrell. 2011. Monitoring soil quality to assess the sustainability of harvesting corn stover. Agron. J. 103:288-295.

Kaspar, T.C., and M.G. Bakker. 2015. Biomass production of 12 winter cereal cover crop cultivars and their effect on subsequent no-till corn yield. J. Soil Water Conserv. 70:353-364. doi:10.2489/jswc.70.6.353

Kenney, I., H. Blanco-Canqui, D.R. Presley, C.W. Rice, K. Janssen, and B. Olson. 2015. Soil and crop response to stover removal from rainfed and irrigated corn. Glob. Change Biol. Bioenergy 7:219-230. doi:10.1111/gcbb.12128

Kong, A.Y., and J. Six. 2010. Tracing root vs. residue carbon into soils from conventional and alternative cropping systems. Soil Sci. Soc. Am. J. 74:1201-1210. doi:10.2136/sssaj2009.0346

Kong, A.Y., and J. Six. 2012. Microbial community assimilation of cover crop rhizodeposition within soil microenvironments in alternative and conventional cropping systems. Plant Soil 356:315-330. doi:10.1007/ s11104-011-1120-4

Lu, Y., S. Lu, R. Horton, and T. Ren. 2014. An empirical model for estimating soil thermal conductivity from texture, water content, and bulk density. Soil Sci. Soc. Am. J. 78:1859-1868. doi:10.2136/sssaj2014.05.0218

Nelson, D.W., and L.E. Sommers. 1996. Total carbon, organic carbon, and organic matter: Laboratory methods. In: D.L. Sparks, editor, Methods of soil analysis. Part 3. SSSA Book Ser. 5. SSSA, Madison, WI. p. 961-1010.

Ochsner, T.E., R. Horton, and T. Ren. 2001. A new perspective on soil thermal properties. Soil Sci. Soc. Am. J. 65:1641-1647. doi:10.2136/sssaj2001.1641

Osborne, S.L., J.M.F. Johnson, V.L. Jin. A.L. Hammerbeck, G.E. Varvel, and T.E. Shumacher. 2014. The impact of corn residue removal on soil aggregates and particulate organic matter. Bioenerg. Res. 7:559-567.

Potter, K.N., R.M. Cruse, and R. Horton. 1985. Tillage effects on soil thermal properties. Soil Sci. Soc. Am. J. 49:968-973. doi:10.2136/ sssaj1985.03615995004900040035x

Puget, P., and L.E. Drinkwater. 2001. Short-term dynamics of root-and shootderived carbon from a leguminous green manure. Soil Sci. Soc. Am. J. 65:771-779. doi:10.2136/sssaj2001.653771x

Richard, G., and P. Cellier. 1998. Effect of tillage on bare soil energy balance and thermal regime: An experimental study. Agronomie 18:163-181. doi:10.1051/agro:19980301

Ruis S., H. Blanco-Canqui, P. Jasa, R. Ferguson, and G. Slater. 2017. Can cover crop use allow increased levels of corn residue removal for biofuel in irrigated and rainfed systems? Bioenerg. Res. 10:992-1004.

SAS Institute, Inc. 2017. SAS OnlineDoc 9.1.3.support.sas.com/onlinedoc/913/ docMainpage.jsp (accessed 1 Mar. 2017).

Sauer, T.J., J.L. Hatfield, and J.H. Prueger. 1996. Corn residue age and placement effects on evaporation and soil thermal regime. Soil Sci. Soc. Am. J. 60:1558-1564. doi:10.2136/sssaj1996.03615995006000050039x

Sheng, Q., and L.A. Hunt. 1991. Shoot and root dry weight and soil water in wheat, triticale and rye. Can. J. Plant Sci. 71:41-49. doi:10.4141/cjps91-005

Soil Survey Staff, Natural Resources Conservation Service, United States Department of Agriculture. 2017. Web soil survey. Available online at the following link: Https://websoilsurvey.sc.egov.usda.gov/. (Accessed 15 Mar. 2017.

Wilhelm, W.W., J.M. Johnson, D.L. Karlen, and D.T. Lightle. 2007. Corn residue to sustain soil organic carbon further constrains biomass supply. Agron. J. 99:1665-1667. doi:10.2134/agronj2007.0150 